\title{
Teaching to the Test or Testing to Teach? Educational Assessment in British Columbia, 1872-2002
}

\section{Alastair Glegg and Thomas Fleming}

Over the years educational assessment in British Columbia has served many purposes in addition to recording student progress. Initially it helped provide evidence that the novel idea of a publicly funded school system was a worthwhile financial and social investment. As schooling expanded so did public examinations, ensuring that content and standards were consistent throughout the province. Between the wars educational priorities dominated assessment, as reformers challenged the validity of traditional testing and the popularity of large-scale assessment and mental testing increased. Recently schooling has become more politicized, and the purposes and methods of assessment have become subjects of public debate, often reflecting the priorities and philosophies of the government in power. Current attitudes to formal assessment appear to be determined by a combination of the factors that have influenced it over the years, and what started as a fairly straightforward concept has become increasingly complex and controversial.

Au fil des ans, l'évaluation pédagogique en Colombie-Britannique a servi à plusieurs fins, outre celle de noter les progrès des élèves. Au début, elle aida à fournir la preuve que l'idée novatrice d'un système scolaire financé par des fonds publics était un investissement financier et social très valable. Les examens publics ont suivi le rythme de la scolarisation, garantissant l'uniformité des contenus et des critères dans toute la province. Durant l'entre-deux-guerres, les priorités éducatives dominèrent l'évaluation, alors que les réformateurs remettaient en question la validité de l'examen traditionnel et que la popularité de l'évaluation à grande échelle et de l'examen mental augmenta. Récemment, la scolarisation est devenue plus politisée et les objectifs et les méthodes d'évaluation sont devenues l'objet de débats publics, reflétant souvent les priorités et les idées du gouvernement en place. Les positions actuelles face à l'évaluation officielle semblent être déterminées par une combinaison de facteurs qui l'ont influencée au fil des ans et, ce qui était à l'origine un concept plutôt simple, est devenu de plus en plus complexe et controversé. 
"Over the years we have tested almost every testable subject."

C. B. Conway, Director, Research and Standards Branch, 1974. ${ }^{1}$

The establishment of formal assessment procedures has generally been an integral part of the development of public school systems, paralleling the growth of administrative structures, and serving many purposes other than evaluation of academic achievement. The very phrase "teaching to the test" indicates that assessment was not only for the students, but for the teachers, to see how successfully they could transmit the required material. Over time the emphasis has shifted from summative to formative purposes, so that lessons can be learned from the results and processes of testing. This article traces the historical development of educational assessment and testing in British Columbia to demonstrate how the formal and informal purposes of assessment changed over time in response to educational, political, administrative, and social needs.

There are several different aspects of assessment and testing in British Columbia which need to be examined. First, there is the actual amount of testing for which central government was responsible: this expanded over the years from tests for teacher certification, to high school entrance examinations, thence to graduation requirements, and eventually to mandatory public examinations at the completion of every grade in high school. In addition to the school-based examinations, there was also the development of province-wide testing, which reached its peak in the 1960 s. $^{2}$ Clearly, when virtually every stage of public schooling is monitored and tested by the Department of Education there is little scope for deviation from the officially prescribed curriculum and standards.

The curriculum itself is the second thing to be considered: as central government sets the examinations it controls not only standards, but the content of schooling, and this is where shifts in policy can most clearly be identified. Third, and following logically from the previous point, is the power to use public examinations as a reflection of a particular philosophy, not only that of the government in power, but also of the individual superintendents and ministers of education, whose personal views on education help shape assessment policy. Next, these shifts in philosophy can be defined more specifically by the importance attached to examinations and

1 British Columbia, Annual Report of the Public Schools 1973-74 (hereafter ARPS) (Victoria: Queen's Printer, 1974), D12.

2 ARPS 1970-71. 
testing: the scrapping of the provincial Grade 12 examinations as a requirement for university entrance in 1973is as clear an indication of government control of acceptable educational philosophy as was the reinstatement of those examinations ten years later by a more conservative government. ${ }^{3}$ Finally, there is the question of determining what use should be made of the results of provincial assessment for educational, administrative, and political purposes. At times all the results have been made public, and at others government has jealously guarded them in case they should be interpreted inappropriately. All these considerations form part of this study of the evolution of centralized testing in British Columbia.

\section{The Early Years: Building a Coherent and Accountable School System}

A primary task of British Columbia's early school leaders was to collect information about the state of the province's schools. One of John Jessop's first official acts after he was appointed Superintendent of Education in 1872 was to write to Dr. J. George Hodgins, Ryerson's Deputy Superintendent in Ontario, requesting copies of "the Chief Superintendent's Reports, the Journal of Education, the new School Act, and other Departmental papers which from time to time are issued from your office." Jessop did so principally to familiarize himself with how the older Ontario system accounted for itself to the public. ${ }^{5}$ As he explained in the conclusion of his second annual report in 1873: "Public schools are entirely a new feature; and parents themselves, in some instances, require to be educated." Colin Campbell McKenzie, Jessop's successor in the superintendent's office, set out the matter of public accountability more directly. "The cost of education is an important question in all countries," he wrote in 1878 , "but in this province it bears an importance it has in no other, as in no other is the total cost borne by the general exchequer."

Jessop, like his mentor Ryerson before him, set out to develop a management information system for provincial schools that would

\footnotetext{
3 ARPS 1973-74; ARPS 1984-85.

$4 \quad$ F. Henry Johnson, John Jessop: Gold Seeker and Educator: Founder of the British Columbia School System (Vancouver: Mitchell Press, 1971), 108.

5 The construction of the informational apparatus to manage schools, students, and teachers in Canada West served as a model for the British Columbia system. See Bruce Curtis, Building the Educational State: Canada West, 1836-1871 (London, ON: The Althouse Press, 1988), 271-98.

6 ARPS 1878-79, 179.
} 
satisfy three criteria - to record educational conditions throughout the province, provide measures of progress and learning and, last but not least, illustrate to the public that provincial revenues directed toward the schools were being carefully and wisely spent. The foundation stone of the information system Jessop and his successors devised was the school register - a simple instrument of record that teachers were obliged to keep and which together with the monthly reports they submitted constituted the first two rungs in the provincial reporting system. The third and fourth rungs of the system were provided, respectively, at the school level by principals and at the district level by school board secretaries in their own monthly and annual aggregations of the monthly reports obtained from teachers. ${ }^{7}$ With classroom, school, and district information in hand, it was a straightforward task for provincial superintendents to summarize the data they obtained from school districts to produce a system-wide statistical portrait of provincial schools.

With this system-wide data in hand, provincial superintendents were able to furnish the legislature with a variety of financial and other information, including expenditures on salaries, buildings, maintenance, and school supplies. Using such information, the superintendents were able to generate a large assortment of statistical tables showing increases in enrolment, the changing gender composition of the student cohort, changes in daily, weekly, monthly, and yearly attendance of pupils and teachers, and a host of intra and inter-district comparisons illustrating teachers' credentials, workloads, educational costs, and pupil performance on examinations.

The Free School Act of 1865 had granted the Governor of the Colony of Vancouver Island the power to appoint a Board of Education to control all school property, to make regulations for teachers, and to prescribe curriculum and textbooks. Teachers and local advisory boards were to be appointed by the governor in what Johnson described as "perhaps the most highly centralized system of public education in North America." Columbia expanded over the years, the basic premise of central control persisted. The provincial Superintendent of Education made the decisions, and his subordinates saw that they were carried out. This was done originally through an inspectorate composed primarily

7 Noteworthy, of course, is the fact that in many of British Columbia's small communities, class-level, school-level, and district-level information were essentially one and the same thing until the mid-twentieth century.

8 F. Henry Johnson, A History of Public Education in British Columbia (Vancouver: University of British Columbia Press, 1964), 32. 
of former principals, who shared with the superintendent a common vision of what schooling should be like during what has been called the Imperial Age of school administration. ${ }^{9}$ Another important instrument of control was the centralized system of examinations, which dictated the curriculum content and set the standards for virtually every aspect of schooling.

The first examination set by the provincial government was the 1873 Teachers' Certification Examination, prepared primarily by Superintendent Jessop, although local scholars and politicians were invited to set some of the papers. Dr. William Fraser Tolmie's paper on "History and English Literature" clearly indicates the sort of teachers the young province was looking for. Out of twenty compulsory questions nearly half dealt with church history, and aspiring teachers were expected to be able to name the early Christian missionaries to Britain as well as the first Archbishop of Canterbury. They were also expected to know the date of the first translation of the Bible into English, and (oddly enough) to be able to list the "useful purposes" of the monasteries. ${ }^{10}$

The next Teachers' Certification Examination gives us another view of the type of individuals the government was anxious to attract to teaching. Gentlemen were asked to write a composition on the influence on civilization of the gold rushes in California and Australia, whereas ladies were asked to respond to the following: "Give your opinion as to the good results which may follow the present agitation on the subject of 'Woman's Rights."'11 This bold foray into progressivism was short-lived, as next year the composition subjects were more succinct and traditional: "Gentlemen - Politics; Ladies Manners."12

An expanding population and the accompanying interest in further education now required the regulation of promotion to high school, and in 1876 the first High School Entrance Examinations were set, consisting initially of short papers on Arithmetic, English Grammar, Geography and Spelling. ${ }^{13}$ This, then, was the real beginning of provincial testing of students, and thereafter growth was rapid. The next to be set was the High School [Leaving] Examination,

9 Thomas Fleming, "In the Imperial Age and After: Patterns of British Columbia School Leadership and the Institution of the Superintendency," in School Leadership: Essays on the British Columbia Experience, 1872-1995, ed. Thomas Fleming (Mill Bay, BC: Bendall Books, 2001), 161-87.

10 ARPS 1873-74, 45

11 ARPS 1874-75, 71.

12 ARPS 1875-76, 153.

13 ARPS 1875-76, 154-56. 
so through examinations the government now regulated standards and curriculum content at the beginning and end of high school. In 1889 high school leavers were asked to write essays on "The Golden Rule" or "The Advantages of Higher Education," and the conscious development of civic and national pride is indicated by the other topics, "Our City," and "Our Exports."14 The government assured itself of a body of Christian teachers by requiring candidates in the composition examination to "Write the Lord's Prayer, being particular as to the use of capitals and punctuation marks." 15 In 1889 control through examination was tightened further. The superintendent was required to prepare the High School Entrance examinations, and a candidate who missed any part would not be allowed to continue on to high school without written permission from the trustees and the consent of the superintendent. ${ }^{16}$

From the comparatively limited range of high school examinations in the late 1870s the number expanded enormously, and by 1896 government examinations, the dreaded "departmentals," were available for twenty-eight subjects. There were specific papers not just on English History, but on Canadian History, Ancient History, Roman History, and General History. Science expanded from the catch-all "Anatomy-Physiology-Hygiene" to include papers on Botany, Zoology, Chemistry, Geology, and Natural Philosophy, while languages included Latin, French, and Greek, although the last was not included in the Annual Report "for want of Greek type in the Government printing office."17

\section{Entering the Twentieth Century: Changing Views of Assessment}

The high school entrance exams were but part of a larger set of exams designed to promote commonality, or what is today referred to as equity, across the system. Until 1923, when the Department of Education adopted an eight-grade system for its elementary schools and applied grades 9, 10,11, and 12 to high school, the high school grades carried no numerical designation. Instruction was divided among five levels of instruction - preliminary junior, advanced junior, intermediate, senior, and senior academic. Completion of the

ARPS 1888-89, lxxxi.

Ibid., xci.

ARPS 1889-90, lxix.

ARPS 1895-96, cvii. 
intermediate level represented the equivalency of grade 11 or junior matriculation. Senior academic represented the completion of secondyear university arts. Departmental exams were set for each of these levels as part of a large testing program that required hundreds of "markers" to assess during the June and July "marking season" at a common location in Victoria.

The Education Office freely admitted that departmental examinations were not always a "true test of knowledge" and that they did "not always determine which is the best scholar." in the absence of better instruments to measure academic performance the exams prevailed because they ensured the provincial curriculum was carefully followed in city and village school alike, they offered a relatively objective measure about which schools, teachers, and pupils performed well or badly, and they set standards for pupils that demanded, as Inspector William Burns put it, "concentration of thought...power of expression, as well as certainty of knowledge."19 Granted, the construction of these entrance exams and their validation of knowledge rather than thought only reinforced alreadystrong tendencies among Victorian and Edwardian teachers toward drill-work and memorization. In many classes, rote-learning became the method of choice to assist pupils in achieving exam success.

By now "from the Maritimes to British Columbia schooling was unified, monopolized, standardized, supervised, professionalized and controlled by the state." ${ }^{20}$ The mechanism of government control was firmly established: a centralized power structure dominated by the superintendent and a hand-picked inspectorate created the Educational Raj, ${ }^{21}$ and the examination system ensured that the Department of Education had the final say in what students were learning and whether they were doing so successfully. Change was gradual, and with few exceptions increased rather than diminished central control. By 1905 the Annual Report was placing much more emphasis on examination marks, and reported results by rank for teaching certificates and high school graduates. The High School Entrance Examination was by then eleven pages long, and there were three separate high school examinations: Junior Grade, Intermediate,

\footnotetext{
18 ARPS 1894, 189

Ibid.

Thomas Fleming, "Canadian School Policy in Liberal and Post-Liberal-Eras: Historical Perspectives on the Changing Social Context of Schooling, 1846-1990," Journal of Education Policy 6, 2 (1991): 187. This was, of course, Ryerson's original objective for public schooling.

21 Fleming, "In the Imperial Age."
} 
and Senior Academic Grade. ${ }^{22}$ The movement towards provincial testing at every grade level was well under way.

A decade later the High School Entrance Examination was becoming less important, although all aspirants to high school still had to write it. Elementary education was becoming more widespread, and the new Normal Schools in Vancouver and Victoria were graduating teachers who were better qualified and presumably better able to make decisions about promotion. The government increasingly turned its attention to regulating the rapidly expanding high schools. In 1916 there were seven different centrally set high school examinations, covering junior, commercial, intermediate and senior levels. ${ }^{23}$ By 1921 entrance to high school could also be by recommendation, the first sign of a relaxation of central authority, ${ }^{24}$ although this is rather misleading as the recommendations for promotion still had to be approved by the provincial or municipal inspector as well as the principal of the high school. ${ }^{25}$ Over 4,000 students wrote the entrance examination, of whom only about half passed, while 1,400 were recommended for promotion. ${ }^{26}$ Control over standards and content was still very evident, even though over the next few years an increasing proportion of students entering high school did so through recommendations. In 1923, 2,788 candidates out of 4,939 passed the entrance examination while 1,791 were recommended for promotion. ${ }^{27}$ The low pass rate seemed to be viewed in a positive light, an assurance that the Department of Education was insisting on high standards, and a reminder that teaching to the test (or at least for the test) was all-important.

\section{Between the Wars: Progressivism and Reaction}

By the mid-1920s the increasing control over high school standards and content was shown by the reliance on provincially set examinations at the end of Grades 9, 10,11 (for Junior Matriculation and Normal School Entrance), and Grade 12 (Senior Matriculation). ${ }^{28}$ The year 1930 marks the last time that High School Entrance

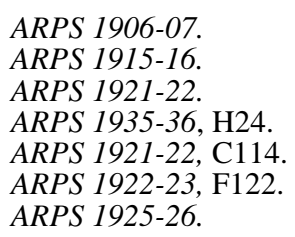


Examinations were published in the Annual Report, ending fifty-five years of direct public access to exactly what students were expected to know in order to enter high school. The High School Examination papers were also omitted from this time on, although they could be purchased from the Officer in Charge of Text Books. ${ }^{29}$ By 1936 over 85 per cent of students entering high school did so through recommendation from their teachers and principals rather than by writing the provincial examination. ${ }^{30}$

This period also saw the rise of what became known as "progressive education," that product of the Enlightenment's idealized vision of childhood, Victorian romanticism, ${ }^{31}$ and a genuine desire for a more humane, sensitive, and individual approach after the horrors of the war, which emerged at the forefront of educational intellectualism as John Dewey's name became a catchword. It is important to remember that the term "progressive" is entirely relative, and that ideas and attitudes which now seem hopelessly outdated and conservative were at one time considered daringly advanced and innovative. A case in point is the reliance on IQ tests, developed during the First World War, which finally gave contemporary educators a scientific basis on which to make decisions about children's ability, potential, and even moral worth, ${ }^{32}$ a technique discredited today but apparently replaced by a similarly unquestioned faith in the psychological assessment of learning disabilities.

The first major review of the British Columbia school system, carried out by J.H. Putman and G.M. Weir in 1925, shows us the approach to education and assessment the progressive educators were looking for. ${ }^{33}$ The commissioners were highly critical of the way the Normal Schools went about producing teachers, and indeed of the graduates themselves. Instructors in the Normal Schools were drawn from the ranks of successful teachers and principals; as practitioners, they were familiar with the challenges to be faced by their students in the ungraded one-room rural schools where most of them would end up, and their emphasis was on the practicalities of lesson preparation,

\footnotetext{
29 ARPS 1930-31, L118.

30 ARPS 1935-36, H24.

31 W.J. Reese, "The Origins of Progressive Education," History of Education Quarterly 42, 1 (2001): 1-24.

32 In this regard see Gerald E. Thomson, " "Remove from our midst these unfortunates': A Historical Enquiry into the Influence of Eugenics, Educational Efficiency as well as Mental Hygiene upon the Vancouver School System and its Special Classes, 1910-1969” (Ph.D. diss., University of British Columbia, 1999).

33 J. H. Putman and G. M. Weir, Survey of the School System (Victoria: King's Printer, 1925).
} 
teaching, and classroom management. This was completely at odds with the view of teacher preparation from the ivory tower of academe, which portrayed the institution as "a laboratory for child study - a place for the observation of child growth." 34 Putman and Weir recommended that the province adopt a regular program of standardized testing to obtain a more accurate assessment of what was being taught and learned. In their view, the "departmentals" were an "outgrowth of an educational system essentially Prussian, rather than British, in spirit," as well as "a hopelessly ineffective method of achieving that system's aims." "35 "If the traditional written examinations were an accurate test of intelligence or educational achievement," they argued, "a strong defence for retaining them as an integral part of the provincial school system could be offered." As evidence that this was not so, they pointed to wild fluctuations in annual failure rates, as well as to Thorndike's findings on the subjectivity of marking, to refute the reliability of such examinations. ${ }^{36}$

The young teachers were thus caught between the rock of conservative practicality and the equally hard place of child-centred intellectualism, although (as Mann has convincingly argued) the progressive education of this period of unrest and uncertainty had just as much to do with the production of good citizens as with the development of individual potential. ${ }^{37}$ The results for teachers were predictable: although there was some movement towards a more progressive approach to teaching, behind the identically painted doors of urban classrooms or the draughty walls of little one-room schools, things remained much the same as "good teachers," according to former pupils and society in general, "emphasized the fundamentals, drilled frequently and tested often...[and] ran no-nonsense classrooms. " ${ }^{38}$ In spite of officially changing views of assessment, the old ways prevailed: tests were there to make clear how much or how

34 J. Calam, "Teaching the Teachers: Establishment and Early Years of the B.C. Provincial Normal Schools," in Schools in the West: Essays in Canadian Educational History, ed. N.M. Sheehan, J.D. Wilson, and D.C. Jones (Calgary: Detselig Enterprises, 1986), 75.

35 Putman and Weir, Survey of the School System, 259-64.

36 Ibid.

37 J. Mann, "G.M. Weir and H.B. King: Progressive Education or Education for the Progressive State?” in Schooling and Society in 20th Century British Columbia, ed. J.D. Wilson and D.C. Jones (Calgary: Detselig Enterprises, 1980), 91-118.

38 N. Sutherland, "The Triumph of Formalism: Elementary Schooling in Vancouver from the 1920s to the 1960s," in Children, Teachers and Schools in the History of British Columbia, ed. Jean Barman, Neil Sutherland, and J. Donald Wilson (Calgary: Detselig Enterprises, 1995), 113-14. 
little students knew, and not to help identify better teaching strategies or encourage awareness of different learning styles.

\section{The Development of Large-Scale Assessment}

The coming of the Great Depression in 1929 made it impossible for the Department of Education to establish an office to prepare tests until 1938, although it did manage to find support for a small "Bureau of Measurements" to function in the Vancouver School District under the direction of former high school principal Robert Straight. ${ }^{39}$ However, by 1938, when the department's fortunes had improved somewhat, the minister's technical advisor, H.B. King, began to look for someone to head a tests and measurements branch within the government's education office.

Clifford Conway, an instructor in statistics at the Ontario College of Education, appeared to be the ideal candidate to take charge of such a unit. Conway was a Manitoban who had earned the respect of his advisor, Peter Sandiford, while studying and working with him during his Ph.D. program at the University of Toronto. ${ }^{40}$ Sandiford, himself a student of Edward Lee Thorndike at Teachers College, Columbia, had been hired by Putman and Weir to administer some 17,000 intelligence tests during the survey of British Columbia schools, the largest single application of such tests since the U.S. Expeditionary Force was dispatched to France in $1917 .{ }^{41}$ The "practical abolition" of high school entrance examinations and the adoption of the high school accreditation process earlier that year (which freed many students from writing departmental exams) made necessary "a more scientific way of evaluating the measurable work of the schools," 42 and Conway was the man to do this. So, for the next thirty-six years, all matters to do with tests and measurements in British Columbia came to fall under his jurisdiction.

Three immediate challenges faced Conway when he took up his post. Following the recommendation of Putman and Weir, he

39 See British Columbia Archives and Records Service (hereafter BCARS), Correspondence, H.B. King to M.E. LaZerte, 19 May 1939, GR 452, Box 1, File 7, Letter 366; and "Robert Straight, City Educator Dies," in The Vancouver Sun, 1 Feb. 1956, 3. 40 Conway had taught science in Toronto city schools "on a temporary basis" while working towards a doctorate in pedagogy at the University of Toronto, which he received in 1937.

41 Putman and Weir, Survey of the School System, 355.

42 BCARS, Correspondence, H.B. King to G.M. Weir, 12 July 1938, GR 452, Box 2, File 3, Letter 71. 
developed a system of province-wide testing to assess scholastic standards in British Columbia. This he did, in his words, "with no regular clerical assistance and no budget." ${ }^{33}$ Within a year of his appointment, Conway administered the first province-wide surveys of reading and grammar since Sandiford's efforts in 1924, and produced objective tests in arithmetic and general science, as well as French and Latin vocabulary. ${ }^{44}$ Interrupted by part-time war service in the armed forces, Conway returned at war's end to his testing program and, in 1947, obtained the first accurate British Columbia norms of the Otis Test of mental ability. He found the average reading ability for grade 11 students to be nine months in advance of the norm of the American sample and achievement levels in arithmetic and language to be higher in large urban schools than in smaller schools. Other tests administered by Conway "showed a steady improvement in knowledge in science by high school students over the scores made in Sandiford's 1925 test, in spite of the fact that high school had become much less selective over the period." 45

From 1947 to 1948, Conway's research and testing division administered some 77,000 achievement tests in general mathematics, general science, handwriting, language arts, reading, and spelling; during the same period, aptitude tests were given to more than 56,000 pupils. Test results, Conway reported, revealed "a tremendous range in terms of grade levels in every subject and every grade that has been tested," a finding not altogether surprising given the cumulative effects of the depression, the war, and post-war immigration on provincial schools. ${ }^{46}$ Conway also set out to reform a matriculation examination system beset by two principal problems - enormous fluctuations in the percentages of failures from year to year, as well as in failure rates across subjects. The Department had concluded that the numbers of pupils who failed the matriculation exams somehow had to be contained "within reasonable limits," 47 and so Conway proposed a radical redefinition of standards. Rather than setting standards "in terms of raw scores or percentage marks," standards would now be defined according to a scale which determined "in

\footnotetext{
43 C.B. Conway, personal papers, "Historical Summaries." We would like to acknowledge the help of Mrs. Ellen Conway in allowing us to see these materials.

44 ARPS 1973-74, D13.

45 Johnson, A History of Public Education in British Columbia, 158.

46 C.B. Conway, "Research and Testing in British Columbia," Canadian Education IV (June 1949): 64.

47 C.B. Conway, "Understandable Standards: The Scaling of University Entrance Examinations,” Canadian Education XI (Sept. 1956): 30.
} 
terms of percentages of students" who would pass or fail, ${ }^{48}$ and in the early 1950s, the Department set the "failure rate" for students writing exams in all "university entrance subjects" at a "constant 15 per cent" and scaled other exams so that the rate of student failure in both "difficult" and "easy" subjects was generally commensurate with the abilities of students taking the test. ${ }^{49}$

As British Columbia's school system expanded rapidly in the two decades after the end of World War II, so did the work of the tests and measurement division. Increased high school retention swelled the number of departmental examination papers written by students from non-accredited schools and scholarship candidates from just under 30,000, in 1957, to a peak of nearly 80,000 in 1965 . Under Conway's direction, almost one hundred province-wide surveys were conducted and one and one-half million pupils tested during this "age of survey testing" in British Columbia, with over 63,000,000 test items marked during the years 1961 to 1965 alone, most of them by hand. ${ }^{50}$

Over this period the examinations at the school level were not emphasized as much in the Annual Reports. The Textbook Branch, responsible for examinations, seemed more concerned with internal matters, and complaints about the shortage of Programmes of Study and Report Cards produced the following pompous reproof: "Surely this is the time when we should all practice the good old adage, 'Waste not, want not."' The Director, Mr. Barr, apparently took more pride in the Branch's "splendid story of hard work, care, and efficiency" as demonstrated by the existence of only fifteen cents in bad debts out of its budget of $\$ 413,000 .^{51}$ The same gentleman was still there a decade later, presenting his twenty-fifth consecutive annual report, ${ }^{52}$ a delightful demonstration of Dr. Peter's Principle.

One hundred years after the first government-set teachers' examination in British Columbia, there was in place a monolithic model of government-controlled schooling, a model in which schoolbased and province-wide assessment played a major role by determining the content, standards, and expectations of the school system. But things were to change, and the final thirty years of the

Ibid., 31.

49 C.B. Conway and Ellen Brown, "The Establishment of University Entrance Standards in Required and Optional Subjects," Canadian Education XI (March 1956): 18.

50 ARPS 1973-74, D13.

51 ARPS 1945-46, 114.

52 ARPS 1955-56, FF137. 
twentieth century saw a number of different approaches to the use of assessment.

\section{The End of the Twentieth Century: Politicization of Educational Assessment}

Between 1970 and 2000 there were seventeen different Ministers of Education for British Columbia. That fact alone would suggest that traditional patterns were unlikely to continue, and when it is also taken into account that the political and philosophical differences between the governing parties were much greater than the old LiberalConservative rivalries, it is hardly surprising that educational assessment should also be handled differently. In 1972 the recently elected New Democratic government began to decentralize control of schooling, including a move towards the local appointment of superintendents. ${ }^{53}$ Requirements for high school graduation were relaxed to allow "schools and pupils to plan appropriate programs," 54 and for internal evaluation of schools to allow for an approach to assessment which was more formative than summative, and which would meet the "sole objective...[of] a continuing program of self improvement." 55

The tightly controlled established examination system was being gradually demolished, to be replaced by a more ideologically appropriate model: students winning scholarships were henceforth to be given a personal cheque for $\$ 200$ rather than a voucher to be applied against post-secondary fees: "no longer are there restrictions on when, where and how the money may be used." 56 The new Minister's first Annual Report hailed the "end of an era":

The school-year 1972/73 was the final one in which Rrgular Departmental Examinations were provided by the Department of Education. This brings to an end an era during which Grade XII graduation...was at least partly determined by performance in final Departmental examinations...Graduation diplomas will be

\footnotetext{
53 Vernon Storey, “Uncertain Days: British Columbia’s School Superintendents and Local Employment," in School Leadership: Essays on the British Columbia Experience, 1872-1995, ed. Thomas Fleming (Mill Bay, BC: Bendall Books, 2001), 347-404.

54 ARPS 1971-72, 13.

55 Ibid.

56 ARPS 1972-73, E29.
} 
issued directly by the school rather than the Department of Education. ${ }^{57}$

Locally developed courses were to be allowed without specific ministerial approval as in the past. ${ }^{58}$ The changes would necessitate "the development of new methods of assessment of programmes and student achievement," and evaluation procedures" was appointed, ${ }^{60}$ and a committee on evaluation was planned, including representation from the British Columbia Teachers' Federation (BCTF), one of the more active supporters of the new government. ${ }^{61}$

The Annual Report for 1974-75 did not appear until after the defeat of the short-lived New Democratic Party government, and thus gives little new information. The very vagueness of the details of assessment reflected a change of perspective: "In the second phase of the [Language Arts] study samples of Grade IV students across the Province were assessed on a series of reading objectives." ${ }^{2}$ Note was taken, however, of the establishment of a separate Learning Assessment Branch, now distinct from the Research Branch. By the next year under a new government a core curriculum for all grades was being developed for implementation by 1977, and a long-range learning assessment program was initiated, ${ }^{63}$ the results of which were to be made public. "The fundamental purpose of the program is to facilitate educational decision-making in areas such as curriculum development, fiscal management, teacher education and research." 64 The new government's right-wing approach was evidently to be very different.

The increased emphasis on the Provincial Learning Assessment Program (PLAP) was made clearer in the next report from the Minister. It was to be used "to monitor the whole public school system, including the core curriculum program. On the basis of test results, changes will be made to curriculum content and methodology and, if it appears desirable, to teacher pre-service and in-service

Ibid.

ARPS 1973-74, D10.

Ibid.

Dr. J. Mussio was appointed to head up the Assessment Programs. In spite of an apparent relaxation of government control, the Division "underwent greater expansion in one year than in the previous 25.” Ibid., D14.

61 Ibid., D10.

62 ARPS 1974-75, 25.

63 ARPS 1975-76, 13

64 Ibid., 15. Emphasis added. 
training." ${ }^{65}$ Its purposes were further clarified in the 1976-77 report: it was to go "beyond the examination of the student's achievement to look into such matters as the training of teachers and the effectiveness of courses," $"$ and it was noted that "a close examination of the Provincial results indicated that a limited number of districts were performing well below expectations." ${ }^{\prime 67}$ Province-wide assessment would now be used to compare performance from district to district. There was also an interesting change in priorities: "The main principle underlying the [assessment] program is that decisions about education (allocating resources, developing in-service teacher-training programs, improving curricula) should be based on an understanding of what and how children are learning." "68 Compare this with the order noted above for 1975-76: "curriculum" has moved to the bottom of the list, and "financial management" to the top. Provincial assessment expanded over this period to include science and physical education, and results were not only published as a whole, but summaries of student achievement were provided to each district for review and action. ${ }^{9}$

The next step on the path to an renewed emphasis on assessment came with the production of a standardized mathematics examination for Grade 12 students, supplementing the other mathematics achievement tests, which had received "overwhelming support." proposed development of government achievement tests for Grades 11 and 12 chemistry and algebra is further evidence of a move back to provincial testing, ${ }^{71}$ and an "achievement test credit allocation plan" was put in place to ensure teachers free access to those tests. ${ }^{72}$ The strategy was clearly successful, as in the 1980-81 school year over half a million tests were provided, and there were "many requests for the ministry to continue to provide materials in more subject areas and grade levels." 73

The financial restraint program of the early 1980s brought a temporary halt to the process, but major province-wide assessments were carried out in mathematics and science, testing 176,000 students

ARPS 1976-77, 10.

Ibid., 13.

Ibid., 14

Ibid., 16. Emphasis added.

ARPS 1977-78, 18.

ARPS 1978-79, 23.

Ibid.

Ibid., 25

ARPS 1980-81, 27. 
from grades 4 to $12 .{ }^{74}$ In 1982, however, because of "renewed interest in careful evaluation at senior secondary levels," ${ }^{75}$ further achievement tests were prepared, and the Program Assessment section gave over ninety workshops on "grading practices." examinations and assessment was restored almost to its previous level with the re-introduction in 1984 of Grade 12 Provincial Examinations in thirteen subjects. ${ }^{77}$ The announced purpose was "to ensure that grade 12 students meet consistent provincial standards of achievement...[and] will be treated equitably when applying for admission to post-secondary institutions," any doubt about who was in charge of determining acceptable achievement levels.

In 1985 the Provincial School Review Committee published the results of a major survey entitled Let's talk about schools. In response to a question as to whether standards should be established and who should set them, 95 per cent of respondents agreed that achievement standards should be established for all forms of schooling. ${ }^{79}$ Over 90 per cent of respondents were in favour of provincial testing at the Grade 12 level. ${ }^{80}$ It is significant that there was a marked difference in the responses from the general public and those from education professionals. Whereas 69 per cent of the general public felt that standardized methods of evaluation were "very important," only 3 per cent of education professionals did so. On the other hand, 85 per cent of education professionals considered standardized methods "not very" or "not at all" important. ${ }^{81}$ The government was correct in concluding that it had broad public support for its assessment program, even if many educators thought differently. By 1985 there were several different provincially administered assessments in place; the Grade 12 Provincial Examinations, the Scholarship Examinations, the General Educational Development Testing Program, and the Learning Assessment Program. These were supplemented by some

ARPS 1981-82, 22.

ARPS 1982-83, 20

Ibid.

ARPS 1983-84, 17.

ARPS 1984-85, 36.

Let's talk about schools. A report to the Minister of Education and the people of British Columbia. 1: Summary and highlights (Victoria: Queen's Printer, 1985$), 17$.

80 Ibid.

81 Let's talk about schools. A report to the Minister of Education and the people of British Columbia. 3: Gallup Survey (Victoria: Queen’s Printer, 1985), 16. 
international comparisons, and by the annual distribution of 750,000 classroom achievement tests. ${ }^{82}$

In 1988 the report of the Royal Commission on Education appeared ${ }^{83}$ and to the surprise of many observers, the government accepted and implemented 75 of the 83 recommendations. ${ }^{84}$ As far as formal testing was concerned, the Commission endorsed the use of Provincial Grade 12 exams, but recommended that their weighting be dropped to one-third of the final grade..$^{85}$ While the Year 2000 Program, developed in response to the Royal Commission, generally took a progressive view of schooling, it continued to emphasize the control of the school system through a new graduation program, ${ }^{86}$ large-scale provincial assessment programs, ${ }^{87}$ and an endorsement of Grade 12 provincial examinations. ${ }^{88}$ A change of minister in 1990 marked a shift away from some of the more innovative aspects of the program, ${ }^{89}$ and the noncommittal language of the reports on assessment reflects this. ${ }^{90}$ But this change was insignificant compared to the major overhaul of the whole system which came with the election in 1991 of the first New Democratic Party government in seventeen years. Change takes time, but even the Annual Report, which primarily covered educational activities during the rule of the previous government, contained one indicator of things to come: a section on "Self-esteem and personal initiative.""1

The final decade of the twentieth century was remarkable in the context of this article not for an emphasis on examinations and assessment, but for the very opposite: an apparent reluctance to base decisions on formal academic testing processes, especially if those

\footnotetext{
82 ARPS 1985-86.

83 A legacy for learners: The report of the Royal Commission on Education (Victoria: Queen's Printer, 1988).

84 Alastair Glegg and Peter Murphy, "Education for the Year 2000: British Columbia," New Education 15, 2 (1993): 21-30. See also Anthony Brummet, Mandate for the School System: Province of British Columbia (Victoria: Queen’s Printer, 1989).

85 A legacy for learners, 108.

86 British Columbia Ministry of Education, Enabling learners. Year 2000: A framework for learning (Victoria: Queen’s Printer, 1990), 15.

87 Ibid., 19.

88 ARPS 1988-89, 35.

89 Education Minister Tony Brummett, who had been a strong advocate for the changes recommended by the Royal Commission, was so disappointed with the cancellation of the Dual-Entry Kindergarten program that he resigned his seat in the Legislature. He was replaced by Stan Hagen, who took a more conservative approach. For further details see Alastair Glegg, "Inquest on a Failure: The Dual-Entry Kindergarten Experiment in British Columbia," International Journal of Educational Reform 4, 1 (1995): 18-24.

90 ARPS 1989-90, 107.

91 ARPS 1990-91, 25.
} 
should be used for purposes of comparison or criticism. It is noteworthy that the Ministry of Education had by 1992 also become the Ministry Responsible for Multiculturalism and Human Rights, and that the first section in the report dealt not with academic achievement, as had generally been the case before, but with diversity: comments on immigrants, single parents, children with special needs, and those for whom English is a second language. ${ }^{92}$ Learning assessment results were differentiated by gender, ${ }^{93}$ and charts showed differences in career expectations for girls and boys. ${ }^{94}$ The traditional provincial assessment program still existed, but was being used in quite a different manner: the Gender Equity Unit of the Ministry ensured that "all provincial curriculum materials are now written and reviewed for gender equity." ${ }^{95}$ Reports were now to de-emphasize hard data and percentages; anecdotal reporting as opposed to letter grades was "required" for Grades 1 to 3, and "encouraged" for Grades 4-7; $;{ }^{96}$ other tools of assessment to be known as educational indicators were planned and later implemented as the School Achievement Indicators Program. ${ }^{97}$

The downplaying of the importance of examinations and formal assessment continued with the proposal to allow students to challenge courses (that is, to be given credit without having to write an examination) and to use outside experience and skills as part of graduation requirements. ${ }^{98}$ Achievement data were to be presented "in a neutral and objective manner" with "minimal interpretive commentary," 99 and the accepted practice of publishing specific marks was replaced with generalities so vague as to be almost meaningless: "the Provincial Learning Assessment Program shows about 80\% of B.C. students were able to write compositions and understand the main ideas when reading materials which were appropriate to their grade levels." 100 The priorities of the government determined the use of testing and assessment in a completely different way. The deliberate emphasis on such matters as Aboriginal rights, socioeconomic considerations, gender equity, and the social pressures of adolescence came at the expense of reporting results of formal

ARPS 1991-92, 16

Ibid., 27.

Ibid., 45.

Ibid., 92.

Ibid., 82.

Ibid., 85; ARPS 1992-93, 11.

ARPS 1993-94, 2.

Ibid., 5.

100 Ibid., 6. 
testing, and in spite of the claim that "intellectual development is the primary goal," parents and the public were beginning to show their doubts: 76 per cent believed that schools were graduating students "with low levels of literacy and numeracy."101 Those warnings, however, were largely ignored, and the section of the 1996-97 Annual Report dealing with academic achievement is headed "Competence" hardly a term which aspires to high standards. ${ }^{102}$

The tone of Education Minister Paul Ramsey's introduction to the next annual report shows how far the New Democratic Party government had moved from the formal academic style of the past:

Parents and teachers alike told me they wanted smaller class sizes for their kids, more teachers' aides to help their kids achieve their full potential, and more classrooms and fewer portables to improve the learning environment for their kids. ${ }^{103}$

In spite of the claim that the ministry played an important role in keeping the public and parents informed about what children were learning and how well they were doing, ${ }^{104}$ the information was vague at best: the frequent use of terms like "most" and "a majority" was accompanied by statements like "an average of 34\% of English 12 students and about $39 \%$ of Maths 12 students have achieved A or B grades in these exams." 105 The vaguest statement on assessment came in the 1998-99 Annual Report in which the minister proudly declared that "most students are performing at a satisfactory level and some are exceeding expectations."106

The response was predictable. When the public, and in this case the parents, are not getting the information from one source, they think they need, they turn elsewhere. In March 1998 a Vancouver newspaper published the results of a study by the right-wing Fraser Institute, which rated and ranked the high schools of British Columbia largely on the basis of Grade 12 examination results, and invited public feedback. ${ }^{107}$ The Ministry of Education was furious, especially as the study was based on its own graduation statistics, and

101 Ibid., 10.

102 ARPS 1996-97, 5.

103 ARPS 1997-98, 1.

104 Ibid.

105 British Columbia Ministry of Education, Key Education Facts 1997-1998, URL www.bced.gov.bc.ca/annualreport/97-98 (1998). Not paginated.

106 British Columbia Ministry of Education, Annual Report 1998-99, URL

www.bced.gov.bc.ca/annualreport/98-99 (1999). Not paginated.

107 “Rating our schools,” Vancouver Province, March 6, 1998, A12-A16. 
denounced the report as misleading and biased. A predictable and spirited debate followed, split clearly along partisan lines, between those who were glad to have at least some measure of comparison between schools, however flawed, and those for whom all comparisons seemed to be odious, particularly those based on academic achievement.

The same debate has been repeated in subsequent years, and the overall reaction can be summed up by this editorial in a major provincial newspaper: "So, knowing the study is flawed, why do we pay so much attention to the results? Because they are all we've got . ..We surrender our children to the schools with little tangible proof that the students are getting the education they deserve." 108 The government however did little to address these concerns, an attitude which took no account of the spreading erosion of a willingness to accept government authority. ${ }^{109}$ On the contrary, in 1999 the ministry announced that it intended to discontinue the release of results of the Provincial Learning Assessment Program. School boards received a letter from the deputy minister stating that assessments would no longer be available because "the results might be used improperly." 110 The decision sparked an outcry, of which this editorial is a typical example:

Parents and students want and deserve to know that schools are delivering the best education possible...yet they are given virtually no information on which to make this assessment...They deserve more information than the paternalistic Education Ministry appears willing to dole out. ${ }^{111}$

Teachers for Excellence in Education, a provincial association which had often criticized the lack of formal testing, put it this way: "The recent decision not to release future school-level data of this program should be of concern to all. It is one thing to desire protection against abuses or excesses of data; it is something else to reject their use for assessment." 112

108 "School ratings fill a vacuum," Victoria Times-Colonist, March 8, 2000, A16.

109 Alastair Glegg, "From Consent to Dissent: Changing Public Attitudes to Government Initiatives in Education in British Columbia, 1865-1995," in School Leadership: Essays on the British Columbia Experience, 1872-1995, ed. Thomas Fleming (Mill Bay, BC: Bendall Books, 2001), 405-23.

110 "Education ministry will halt assessments," Prince George Citizen, Feb. 18, 1999, 5.

111 "Don’t hide data about schools," Victoria Times-Colonist, March 18, 1999, A14.

112 “Such ado about PLAP,” TFE Report 6, 1, (April 1999): 1. 
Two years later the New Democratic Party government was soundly defeated in a general election and replaced by the more rightwing Liberal party. There is already evidence of a swing back towards a greater emphasis on formal testing and assessment, something which it seems much of the public wants, not necessarily for its own sake, but as a measure of accountability that can serve to monitor both the school system and the achievement of individual students.

CENTRALIZED assessment procedures and practices have played a major role in the history of education in British Columbia, and have reflected the administrative, educational, social, and political priorities of the various time periods. Initially the need for educational as well as financial accountability was predominant, as the early superintendents tried to bring some sort of order and coherence to the scattered school system, and to convince both government and voters that publicly funded universal education was essential to the development of the province. As the system became more established, assessment at all levels provided an instrument of centralized control whereby the Department of Education could establish the rules and ensure compliance. A strictly monitored curriculum and examination system, implemented in most cases by poorly trained teachers, naturally led to teaching to the test; those teachers would probably be surprised that their methods and goals might later be considered inappropriate.

As educational theory developed, leaning towards a more progressive approach and involving better-trained teachers, so did assessment. Large-scale testing began to provide information that went far beyond the individual performance of students and teachers, encouraging researchers and practitioners to learn from the results. What this led to, however, was typical of many educational debates: a polarization of views of assessment into two camps, roughly corresponding to the terms summative and formative. These views then began to be associated with broader political beliefs: conservative governments tended to emphasize accountability, and more left-wing governments stressed social development and responsibility, encouraging educational assessment in British Columbia to change course in response to the prevailing political winds. Proponents of one approach are apt to demonize the other: a lack of formal examinations is disparaged as "social promotion"; "teaching to the test" has come to imply a mindless learning process, not a careful coverage of the prescribed curriculum; comparisons between schools 
Teaching to the Test or Testing to Teach?

and districts are seen either as essential for informed decision-making by parents and authorities, or else as promoting social discrimination and bias. It is unfortunate that the rhetoric of party and academic politics tends to obscure the fact that, historically, assessment has had many purposes, and that these can comfortably co-exist. 